\title{
Sex chromosome pre-reduction in male meiosis of Lethocerus patruelis (Stål, I 854) (Heteroptera, Belostomatidae) with some notes on the distribution of the species
}

\author{
Snejana Grozeva', Valentina G. Kuznetsova², Nikolay Simov ${ }^{3}$, \\ Mario Langourov ${ }^{3}$, Svetla Dalakchieva ${ }^{3}$
}

I Institute of Biodiversity and Ecosystem Research, Bulgarian Academy of Sciences, Tsar Osvoboditel Blvd 1, 1000 Sofia, Bulgaria 2 Zoological Institute, Russian Academy of Sciences, Universitetskaya nab. 1, 199034 St Petersburg, Russia 3 National Museum of Natural History, Bulgarian Academy of Sciences, Tsar Osvoboditel Blvd 1, 1000 Sofia, Bulgaria

Corresponding author: Snejana Grozeva (sgrozeva@yahoo.com)

Academic editor: Alexi Popov | Received 23 November 2012 | Accepted 18 April 2013 | Published 30 July 2013

Citation: Grozeva S, Kuznetsova VG, Simov N, Langourov M, Dalakchieva S (2013) Sex chromosome pre-reduction in male meiosis of Lethocerus patruelis (Stål, 1854) (Heteroptera, Belostomatidae) with some notes on the distribution of the species. In: Popov A, Grozeva S, Simov N, Tasheva E (Eds) Advances in Hemipterology. ZooKeys 319: 119-135. doi: $10.3897 /$ zookeys.319.4384

\begin{abstract}
The karyotype and meiosis in males of giant water bug Lethocerus patruelis (Heteroptera: Belostomatidae: Lethocerinae) were studied using standard and fluorochrome ( $\mathrm{CMA}_{3}$ and DAPI) staining of chromosomes. The species was shown to have $2 \mathrm{n}=22 \mathrm{~A}+2 \mathrm{~m}+\mathrm{XY}$ where $2 \mathrm{~m}$ are a pair of microchromosomes. NORs are located in $\mathrm{X}$ and $\mathrm{Y}$ chromosomes. Within Belostomatidae, L. patruelis is unique in showing sex chromosome pre-reduction in male meiosis, with the sex chromosomes undergoing reductional division at anaphase I and equational division at anaphase II. Cytogenetic data on the family Belostomatidae are summarized and compared. In addition, the structure of the male internal reproductive organs of $L$. patruelis is presented, the contemporary distribution of L. patruelis in Bulgaria and in the Northern Aegean Islands is discussed, and the first information about the breeding and nymphal development of this species in Bulgaria is provided.
\end{abstract}

\section{Keywords}

Karyotype, NOR, meiosis, sex chromosome pre-reduction, male reproductive organs, distribution, Lethocerus patruelis, Belostomatidae, Heteroptera

Copyright Snejana Grozeva et al. This is an open access article distributed under the terms of the Creative Commons Attribution License 3.0 (CC-BY), which permits unrestricted use, distribution, and reproduction in any medium, provided the original author and source are credited. 


\section{Introduction}

The genus Lethocerus Mayr, 1853 is a member of the family Belostomatidae (electric light bugs, toe biters), the subfamily Lethocerinae (Perez Goodwin 2006). The giant water bug Lethocerus patruelis is the largest European true bug and the largest European water insect. The adult bugs reach $80 \mathrm{~mm}$ in length. The information on the karyotypes of the genus Lethocerus has been recently summarized by Bardella et al. (2012). In Lethocerus species, chromosome numbers vary from $2 \mathrm{n}=4$ to $2 \mathrm{n}=\mathrm{ca}$. 30 with intermediate numbers of $2 n=8,26$ and 28. The cytogenetic mechanisms of sex determination are also diversified with $\mathrm{XY}$, neo-XY and multiple $\mathrm{X}_{\mathrm{n}} \mathrm{Y}$ encountered in different species. In several species, a pair of $\mathrm{m}$-chromosomes (= microchromosomes) has been described (Ueshima 1979). As is common in Belostomatidae and in Heteroptera as a whole, all so far studied species of Lethocerus have been shown to have an inverted meiosis for the sex chromosomes in males (the so-called "sex chromosome post-reduction") with the sex chromosomes undergoing equational separation during the first division while reductional segregation during the second division (Ueshima 1979, Papeschi and Bressa 2006, Bardella et al. 2012).

In the present work, we studied for the first time the structure of the internal reproductive organs, karyotype and meiosis in males of Lethocerus patruelis (Stål, 1854). In addition, we summarize here data on the contemporary distribution of $L$. patruelis in Bulgaria and in the Northern Aegean Islands, and provide the first information on the reproduction of this species in Bulgaria.

\section{Material and methods}

\section{Insects}

Males of Lethocerus patruelis were collected in 2001-2012 in different regions of southern Bulgaria. Collections were made either in water bodies using plankton net or (predominantly) by light traps. Two adults and three larvae were reared in the laboratory using small fishes (Gambusia affinis, Pseudorasbora parva and Carassius gibelio) as a food. Cytogenetic study was based on three males collected in the area of the border checkpoint Kapitan Andreevo, Bulgaria.

Specimens examined: BULGARIA: Black Sea Coast: Burgas, Lukoil Oil Refinery, 29 m a.s.l., May 2011, 4 specimens, K. Popov leg.; Tundzha River Valley: Kazanlak, 370 m a.s.l., 15.x.2012, 1으. Z. Antonova leg.; Elhovo, 113m a.s.l., October 2011, at light, 1q, G. Hristov leg.; Maritsa River Valley: Kapitan Andreevo Checkpoint, $46 \mathrm{~m}$ a.s.l.: August-September 2011, at light, more than 60 specimens per night, E. Galabova obs.; 5.ix.2011, at light, 20, 4우, S. Grozeva leg.; 5.x.2011, 4ત, E. Galabova leg.; 12.x.2012, 10, at light, E. Galabova leg.; Plovdiv, Plovdiv Thermal Power Station, $170 \mathrm{~m}$ a.s.l., October 2011, 19 and more than 70 specimens observed in the sewer, Zh. Vlaykov leg; Plovdiv, $168 \mathrm{~m}$ a.s.l., autoparking in the northern part 
of the town, 19.viii.2012, at light, 2 specimens, V. Dimitrov obs.; Peshtera, $435 \mathrm{~m}$ a.s.l., October 2011, 1 specimen dead on the road, D. Kajnarov obs.; Eastern Rhodopes Mts.: Madzharovo, Vulture Center, above Arda River, 160 m a.s.1., 16.ix.2009, in light trap, 2丹, 1으. B. Zlatkov leg.; Kresna Gorge: above Oshtavska River, 315 m a.s.l., 10.x.2004, at light, 3 specimens, S. Beshkov leg.; Tisata reserve, $250 \mathrm{~m}$ a.s.l., 13.x.2012, at light, 1 , B. Zlatkov \& O. Sivilov leg.; Struma River Valley: Rupite, $115 \mathrm{~m}$ a.s.l., 20.viii.1997, 1 specimen, at light, M. Langourov leg.; Marena artificial pond close to General Todorov Village, $104 \mathrm{~m}$ a.s.l.: 28.vi.2009, 1q, on the vegetation above water surface, V. Gashtarov obs.; 01.viii.2011, 1 q, in the water, M. Langourov leg.; 25.vii.2012, 3 larvae and 2 exuviae, in the water, N. Simov leg.; quarry near General Todorov Village, $113 \mathrm{~m}$ a.s.1., 23.x.2010, 1§, in a puddle near the road, B. Zlatkov \& O. Sivilov leg.; MACEDONIA: Dojran Lake, 144 m a.s.l., 1996-1997, many specimens, V. Krpach obs.; GREECE: Thassos Island: Astris Village, Astris Beach, 7.ix.2011, 1, dead on the beach, N. Simov \& M. Langourov leg.; Astris Village, small beach $N$ of Astris, 9.ix.2010, 1 , in the sea, N. Simov \& T. Stefanov leg.; Pefkari, 7 m a.s.l., 3.ix.2010, 1ठ̄, dead under street lamps, T. Stefanov leg.

\section{Preparations}

To examine the internal reproductive organs, the abdomen of chloroform-anaesthetized males was opened and the entire reproductive system was dissected. For chromosome studies, the gonads were dissected out from the adults and fixed in Carnoy's fixative consisting of $96 \%$ ethanol and glacial acetic acid $(3: 1)$ and stored at $4{ }^{\circ} \mathrm{C}$. Cytological preparations were made by squashing a piece of the testis in a drop of $45 \%$ acetic acid on a slide. The coverslip was removed using a dry-ice technique (Conger and Fairchild 1953).

\section{Standard staining of chromosomes}

For this staining, the method described in Grozeva et al. (2010) with minor modifications was used. The preparations were first subjected to hydrolysis in $1 \mathrm{~N} \mathrm{HCl}$ at $60^{\circ} \mathrm{C}$ for $8 \mathrm{~min}$ and stained in Schiff's reagent for $20 \mathrm{~min}$. After rinsing thoroughly in distilled water, the preparations were additionally stained in 4\% Giemsa in Sorensen's buffer, $\mathrm{pH}$ 6.8 for $20 \mathrm{~min}$, rinsed with distilled water, air-dried, and mounted in Entellan.

\section{Fluorochrome staining of chromosomes}

For revealing the base composition of C-heterochromatin, staining by GC-specific chromomycin $\mathrm{A}_{3}\left(\mathrm{CMA}_{3}\right)$ and AT- specific 4-6-diamidino-2-phenylindole (DAPI) was used following the method described in Grozeva et al. (2010). C-banding pretreatment was carried out using $0.2 \mathrm{~N} \mathrm{HCl}$ at room temperature for $30 \mathrm{~min}$, followed by $7-8 \mathrm{~min}$ 
treatment in saturated $\mathrm{Ba}(\mathrm{OH})_{2}$ at room temperature and then an incubation in $2 \mathrm{xSSC}$ at $60^{\circ} \mathrm{C}$ for $1 \mathrm{~h}$. The preparations were then stained first with $\mathrm{CMA}_{3}(0.4 \mu \mathrm{g} / \mathrm{ml})$ for 25 min and then with DAPI $(0.4 \mu \mathrm{g} / \mathrm{ml})$ for $5 \mathrm{~min}$. After staining, the preparations were rinsed in the McIlvaine buffer, $\mathrm{pH} 7$ and mounted in an antifade medium $(700 \mu \mathrm{l}$ of glycerol, $300 \mu \mathrm{l}$ of $10 \mathrm{mM}$ McIlvaine buffer, $\mathrm{pH} 7$, and $10 \mathrm{mg}$ of $\mathrm{N}$-propyl gallate).

\section{Microscopy}

The chromosome preparations were examined using the light and fluorescent microscope Axio Scope A1 with digital camera ProgRes MFcool Jenoptik at 100× magnification.

\section{Results}

\section{Testes}

In L. patruelis males, the internal reproductive organs consisted of a pair of testes united by vasa deferentia $(v d)$ with a median unimpaired tube, ductus ejaculatorius $(d e)$ (Fig. 1). Each vas deferens was dilated to form a large vesicula seminalis $(v s)$. The testes were colorless and spherical in form, and each consisted of a single very long tube (seminal follicle) rolled up into a ball. The follicle decreased in diameter from the apex to the vas deferens and showed synchronized divisions in different parts, with only sperms in its thinner part. There were no bulbus ejaculatorius and accessory glands.

\section{Male karyotype and meiosis}

All three studied L. patruelis males presented the same chromosome complement. Spermatogonial metaphases showed 26 chromosomes including four larger and two very small ones, and the rest of the chromosomes formed a gradual size row. There was also a pair of very small m-chromosomes (= microchromosomes) (Fig. 2b) but these were not apparent in many nuclei (Fig. 2a). The chromosomes had no primary constrictions, i.e. centromeres. Two of larger chromosomes showed each a subtelomeric unstained gap, or secondary constriction, representing the nucleolus organizing region (NOR). These chromosomes are X and Y sex chromosomes as was revealed by the observation of meiotic stages (see below).

During meiotic prophase, the sex chromosomes were united and visible as a large, positively heteropycnotic body brightly fluorescent after $\mathrm{CMA}_{3}$ staining (Fig. 3). Cells at metaphase I (MI) showed 13 bivalents, including a small and negatively heteropycnotic pair of $\mathrm{m}$-chromosomes $(\mathrm{n}=13)$. At this stage, all bivalents were distributed randomly relative to each other. Distinguishing between bivalents of autosomes and XY pseudobivalent involved difficulties since the latter was only slightly heteromorphic in 


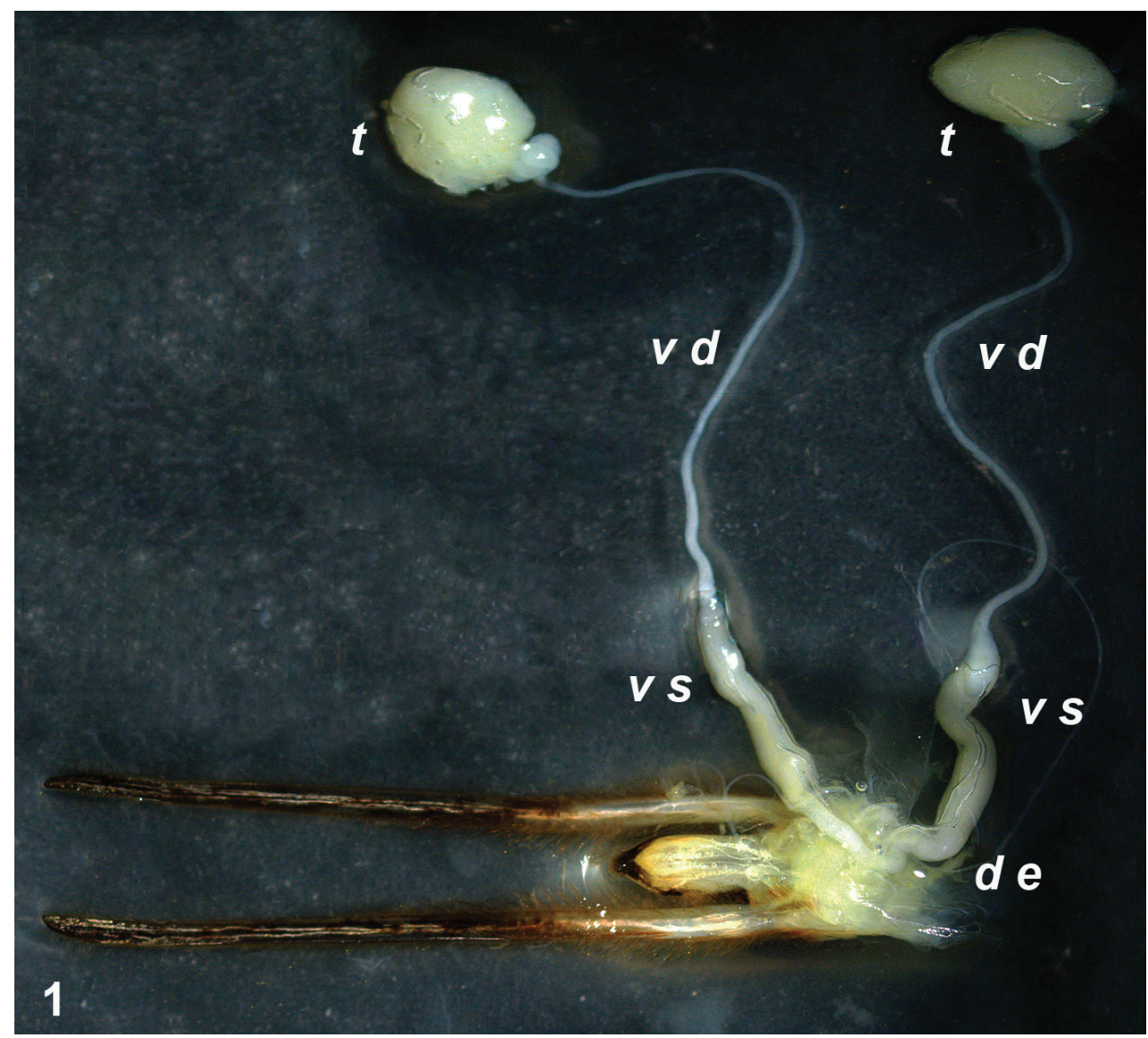

Figure I. Internal male reproductive system: $\boldsymbol{t}$ testis; $\boldsymbol{v} \boldsymbol{d}$ vas deferens; $\boldsymbol{v} \boldsymbol{s}$ vesicula seminalis $\boldsymbol{d} \boldsymbol{e}$ ductus ejaculatorius.

form due to the size resemblance of $\mathrm{X}$ and $\mathrm{Y}$ chromosomes (Fig. 4). However $\mathrm{CMA}_{3}$ staining appeared a foolproof method for the identification of sex-pseudobivalent as one of the largest pairs with GC-rich NORs located in X and Y chromosomes (Fig. 5). At anaphase I (AI), all the chromosomes segregated to opposite poles resulting in two daughter metaphase II (MII) cells with $11 \mathrm{~A}+\mathrm{m}+\mathrm{X}$ and $11 \mathrm{~A}+\mathrm{m}+\mathrm{Y}$, respectively (Fig. 6a). In the studied MII plates, $\mathrm{X}$ and $\mathrm{Y}$ - chromosomes were distributed randomly among other chromosomes (Fig. 6b). DAPI staining did not reveal any differentiation along the length of the chromosomes (Fig. 7).

\section{Notes to the distribution and reproduction in Bulgaria}

In 2008 and 2011, we collected adult specimens of L. patruelis in water bodies in Struma River Valley near Rupite (Bulgaria). Several water bodies in Struma River Val- 

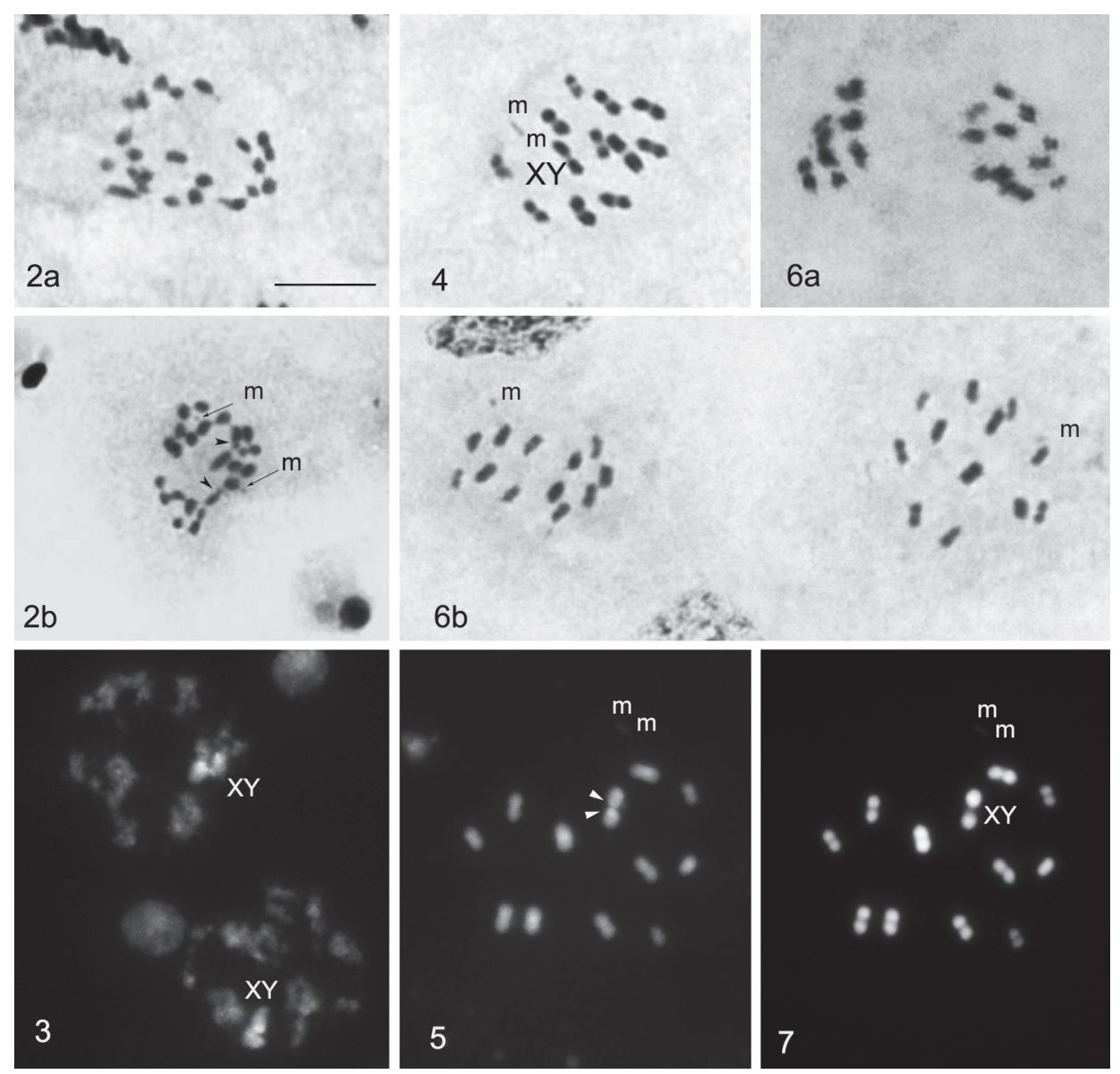

Figure 2-7. 2 Spermatogonial metaphases: two of larger chromosomes, $\mathrm{X}$ and $\mathrm{Y}$, each show a subtelomeric unstained gap, representing the nucleolus organizing region (NOR) (arrow head) (routine staining) 3 Meiotic prophase: sex chromosomes are visible as a large, positively heteropycnotic and brightly fluorescent body $\left(\mathrm{CMA}_{3}\right.$ staining) 4 Metaphase I ( $=13$ ) (routine staining) 5 Metaphase I: GC-rich NORs located on both $\mathrm{X}$ and $\mathrm{Y}$ chromosomes ( $\mathrm{CMA}_{3}$ staining) 6 After the first meiotic division all the chromosomes segregate to opposite poles (6a) resulting in two daughter MII cells (6b) with 13 elements each, $11 \mathrm{~A}+\mathrm{m}+\mathrm{X}$ and $11 \mathrm{~A}+\mathrm{m}+\mathrm{Y}$, respectively (routine staining) 7 Metaphase I: DAPI staining did not reveal any differentiation along the length of the chromosomes. Bar $=10 \mu \mathrm{m}$.

ley, close to these localities were checked by plankton net, and in July 2012, four larvae and five exuviae were found in the Marena artificial pond near General Todorov Village representing thus the first evidence of breeding of L. patruelis in Bulgaria. Marena would be classified as semi-natural mesotrophic to eutrophic lake with macrophytic vegetation (Tzonev et al. 2011). The hydrophytic coenoses in Marena make complexes with various hygrophytic communities, e.g. strips or patches of Typha spp., Scirpus lacustris, tall sedges (Carex spp.). Submerged vegetation are mixed by Myriophyllum and Potamogeton. Larvae were found close to the shoreline, in the regions with submerged 
vegetation. In laboratory, we observed that larvae and adults had used the stems of Myriophyllum as resting place or during stalking/ambush attacks against their preys (electronic supplementary material, video $S 1$ ).

\section{Discussion}

The range of L. patruelis includes Balkan Peninsula, Anatolia, Israel, Syria, Saudi Arabia, Yemen, the United Arab Emirates, Kuwait, Iraq, Iran, Afghanistan, Oriental Region (Pakistan, India, Nepal, Burma), and recently this species was recorded from Italy (Polhemus 1995, Protić 1998, Perez Goodwyn 2006, Olivieri 2009, Fent et al. 2011).

In Bulgaria, only few records of $L$. patruelis specimens migrating from southern parts of the Balkan Peninsula, attracted to light, were published up to 2000 year (Buresch 1940; Josifov 1960, 1974, 1986, 1999) (Fig. 8). During the last ten years, many new findings of $L$. patruelis were made by us in Bulgaria: Kresna Gorge, eastern Rhodopes, Maritsa River Valley (from Kapitan Andreevo to Peshtera) and southern Black Sea Coast (near Burgas). In some of these regions, this species was very abundant; more than 60 specimens per night were attracted to light (Kapitan Andreevo Checkpoint, August-September 2011).

A number of facts (records of the breeding population in Marena; the existence of similar habitats in other regions with records of $L$. patruelis at light; the last years' tendency to milder winters) led us to suppose that this species would breed successfully also in other regions in southern Bulgaria (Maritsa River Valley, Burgas lakes). If such is the case, it would be a further evidence of the recent changes of European bug fauna caused by climate changes and global warming (Rabitsch 2008).

We have studied L. patruelis in respect of male reproductive organs, karyotype and meiosis. The internal reproductive system in this species appeared to be quite similar to that in Diplonychus rusticus (Fabricius, 1871) (Belostomatinae), the only belostomatid species studied so far on this point (Pendergrast 1957, as Sphaerodema rusticum). In $L$. patruelis, each testis consists of the only follicle which is rolled up into a ball; each vas deferens is dilated to form a large vesicula seminalis; bulbus ejaculatorius (representing usually, if present, a dilated anterior end of the ductus ejaculatorius) and accessory glands (diverticula of the ductus ejaculatorius) are absent. Pendergrast (1957) found a similar condition in D. rusticus, however he did not provide information about the number of follicles in testes.

We found that $L$. patruelis had $2 \mathrm{n}=26(22+2 \mathrm{~m}+\mathrm{XY})$. The eight Lethocerus species studied so far with respect to karyotypes (Table 1) represent a large proportion of the 22 species currently known in this genus (Perez Goodwyn 2006). Hence, some preliminary inferences about cytological features of Lethocerus and also of the family Belostomatidae as a whole can be deduced.

Belostomatidae are composed of 3 subfamilies (Belostomatinae, Horvathiniinae, Lethocerinae) with 10 genera and approximately 150 species (Lauck and Menke 1961, Schuh and Slater 1995, Perez Goodwyn 2006, Ribeiro 2007). Up to now, there have 


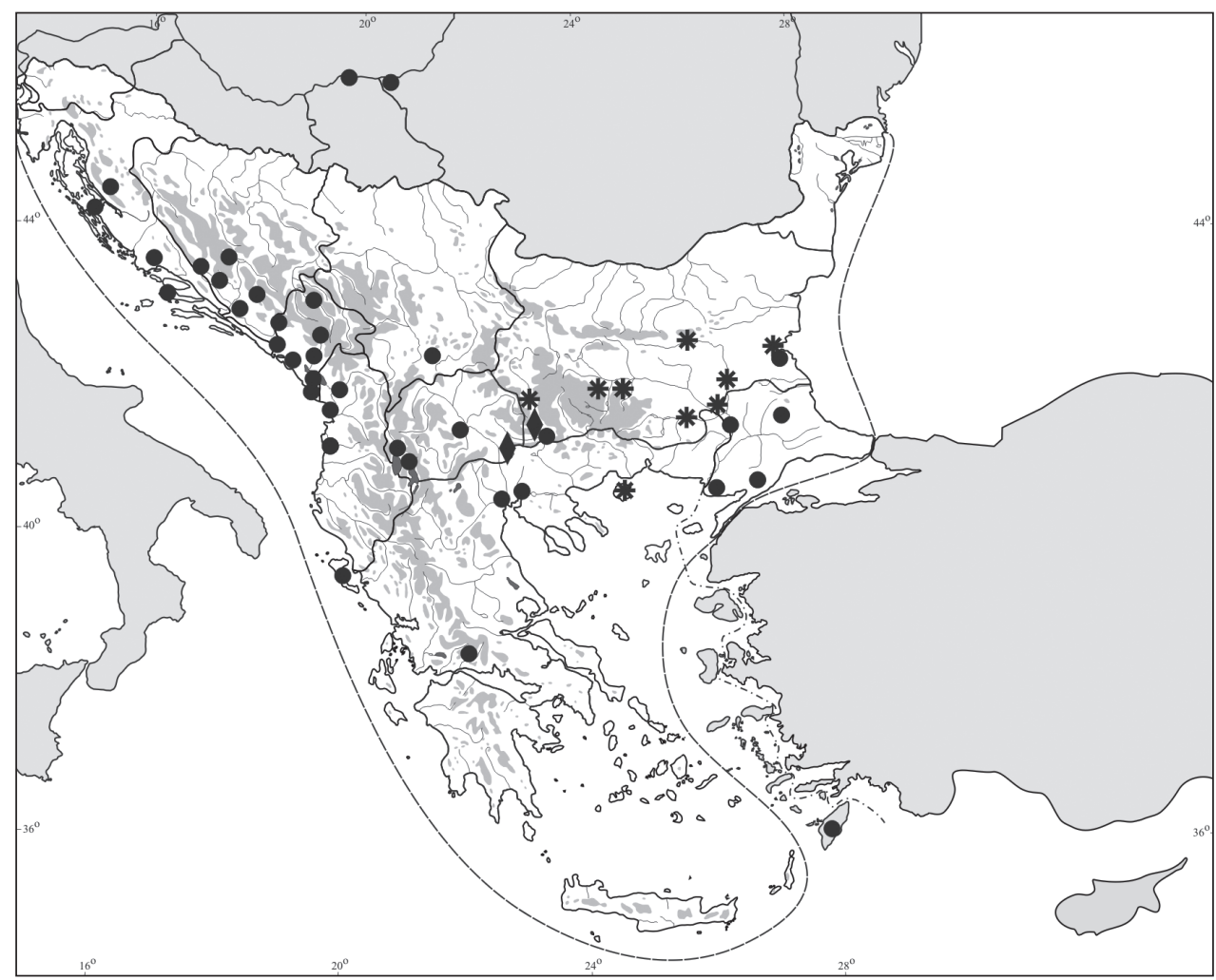

Figure 8. Distribution of Lethocerus patruelis (Stål, 1854) on Balkan Peninsula: • published records; $\checkmark$ new records with data of breeding; * new records of specimens attracted to light.

been cytogenetically analyzed 32 species of the following 6 genera: Abedus (1 species), Belostoma (18 species) and Diplonychus (3 species) from Belostomatinae and Benacus (1 species), Kirkaldyia (1 species) and Lethocerus (8 species) from Lethocerinae (Table 1). In Belostomatidae, chromosome numbers vary from $2 \mathrm{n}=4$ in Lethocerus sp. from Michigan to $2 \mathrm{n}=\mathrm{ca}$. 30 and $2 \mathrm{n}=30$ in L. uhleri and Belostoma dilatatum, respectively. Similarly, the cytogenetic mechanisms of sex determination are variable. Among those, there is the simple $\mathrm{XY}$ system (inherent in each of the genera), and the derived neo-XY (in Lethocerus) and multiple $\mathrm{X}_{1} \mathrm{X}_{2} \mathrm{Y}$ or $\mathrm{X}_{1} \mathrm{X}_{2} \mathrm{X}_{3} \mathrm{Y}$ (in Belostoma) systems. In several species, both from Belostomatinae (Belostoma and Diplonychus) and Lethocerinae (Lethocerus), the presence of $\mathrm{m}$-chromosomes has been reported.

The genus Lethocerus shows a fairly wide range of chromosome numbers, with both extreme for Belostomatidae $2 \mathrm{n}=4$ and $2 \mathrm{n}=\mathrm{ca}$. 30 , and three intermediate ones of $2 \mathrm{n}=8,26$ and 28 (Table 1). The species studied share the conventional cytological features of Heteroptera, such as holokinetic chromosomes (lacking centromeres, that facilitates karyotype evolution via occasional fusion/fission events; Kuznetsova et al. 2011), an XY sex chromosome system (with derivative neo- $X Y$ and multiple $\mathrm{X}_{\mathrm{n}} \mathrm{Y}$ systems presumed to be inherent in three species), and m-chromosomes (detected to date 


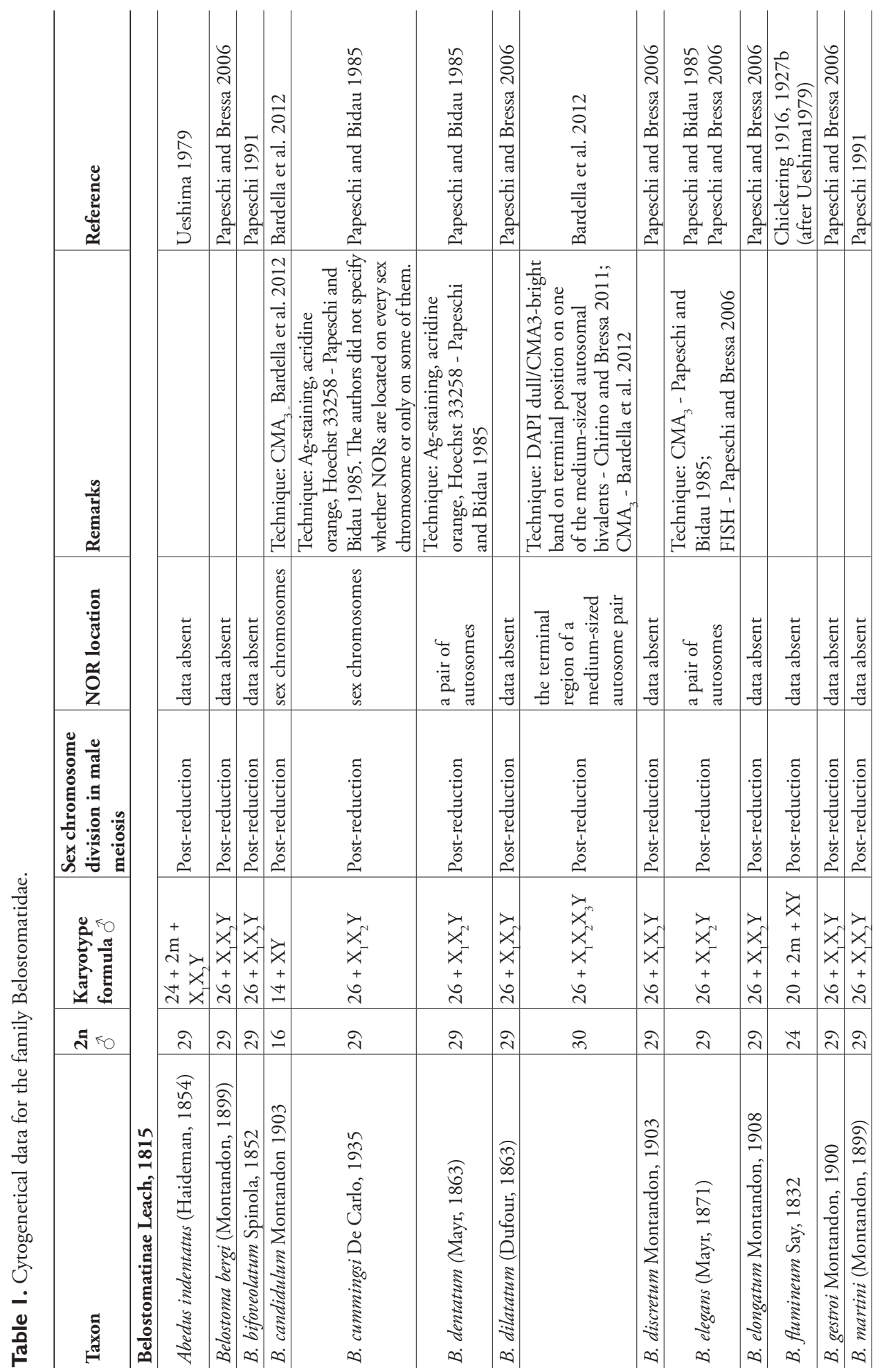




\begin{tabular}{|c|c|c|c|c|c|c|c|c|c|c|c|c|}
\hline 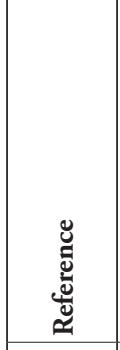 & 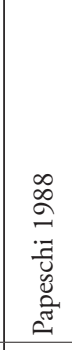 & 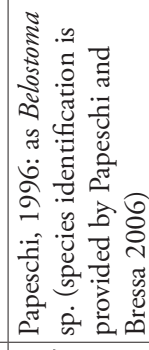 & 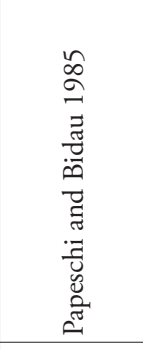 & 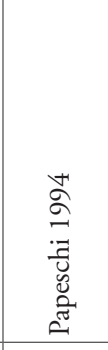 & 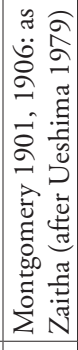 & 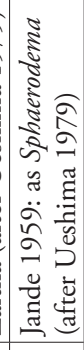 & 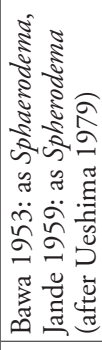 & 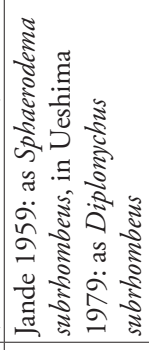 & & 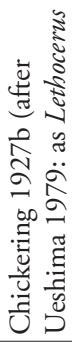 & 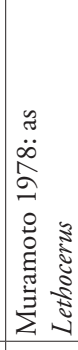 & 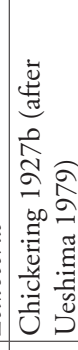 \\
\hline 电 & 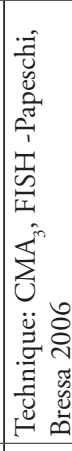 & 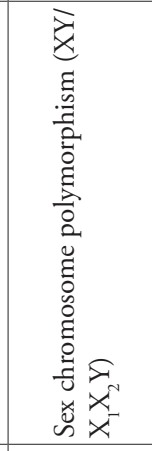 & 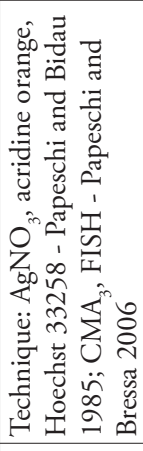 & 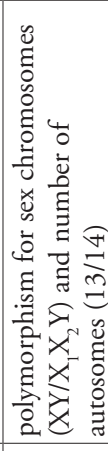 & & & & & & & & \\
\hline 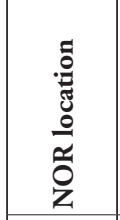 & 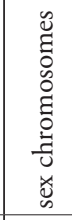 & 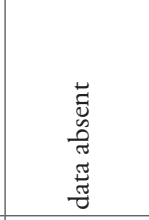 & 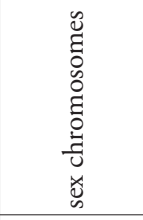 & 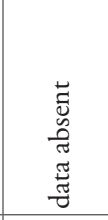 & 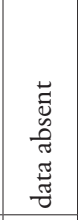 & 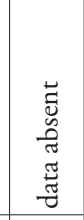 & 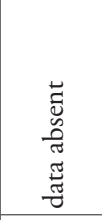 & 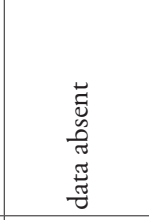 & & 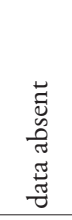 & 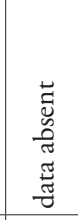 & 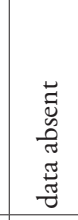 \\
\hline 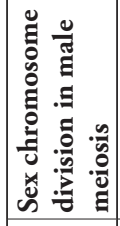 & 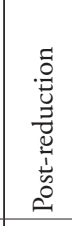 & 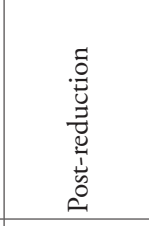 & 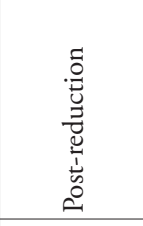 & 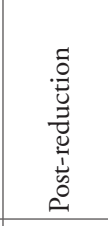 & 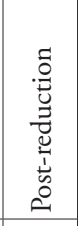 & 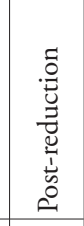 & 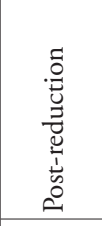 & 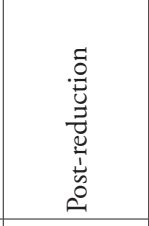 & & 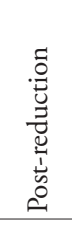 & 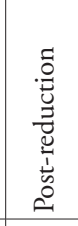 & 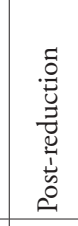 \\
\hline 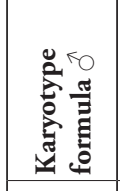 & $\begin{array}{l}\overleftrightarrow{x} \\
+ \\
\pm \\
\end{array}$ & $\begin{array}{l}\searrow \\
+ \\
+ \\
\pm \\
\end{array}$ & $\begin{array}{l}\vec{x} \\
+ \\
0\end{array}$ & $\begin{array}{l}\grave{x} \\
+ \\
\pm \\
\pm\end{array}$ & 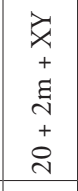 & 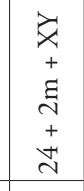 & 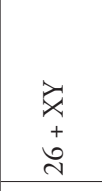 & $\begin{array}{l}\grave{x} \\
+ \\
\stackrel{0}{2} \\
\end{array}$ & & 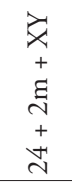 & $\begin{array}{l}\grave{x} \\
+ \\
\stackrel{y}{+} \\
\end{array}$ & $\begin{array}{l}\grave{\lambda} \\
+ \\
+\end{array}$ \\
\hline तี ${ }^{\circ} 0$ & $\stackrel{\odot}{\ddots}$ & $\stackrel{0}{-}$ & $\infty$ & $\stackrel{0}{\ddots}$ & $\stackrel{\sim}{d}$ & $\stackrel{\infty}{\sim}$ & $\stackrel{\infty}{\sim}$ & $\stackrel{\infty}{\sim}$ & & $\stackrel{\sim}{\sim}$ & $\stackrel{\sim}{N}$ & $\infty$ \\
\hline 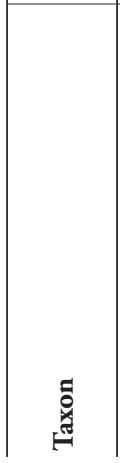 & 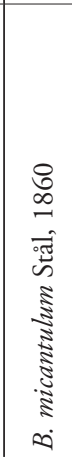 & 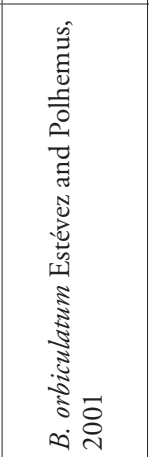 & 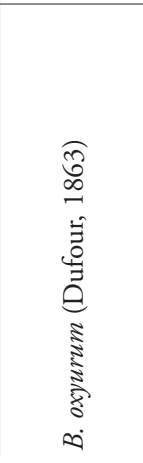 & 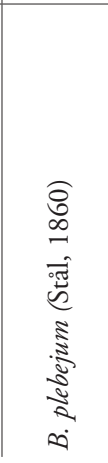 & 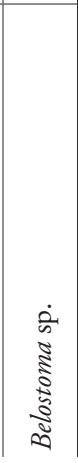 & 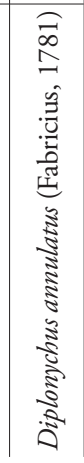 & 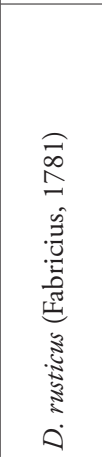 & 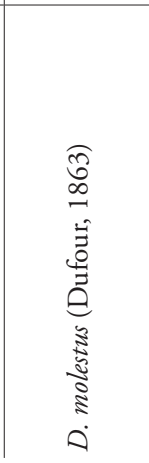 & 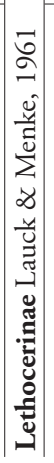 & 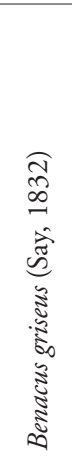 & 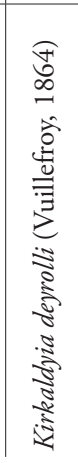 & 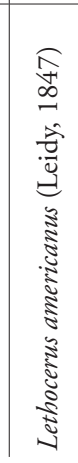 \\
\hline
\end{tabular}




\begin{tabular}{|c|c|c|c|c|c|c|c|}
\hline 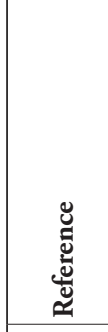 & 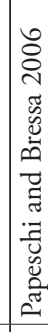 & 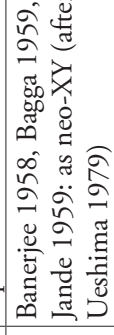 & 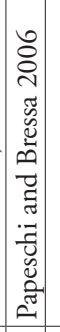 & 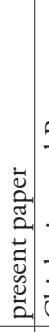 & 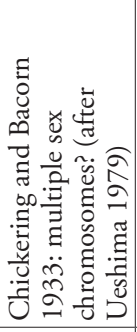 & 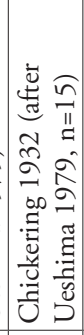 & 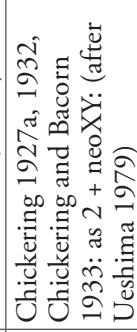 \\
\hline हี & & & & 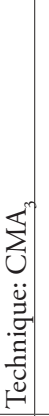 & & & \\
\hline 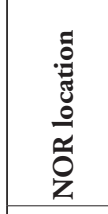 & 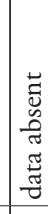 & 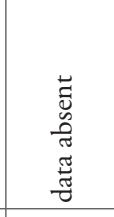 & 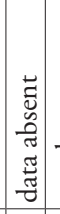 & 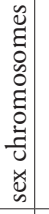 & 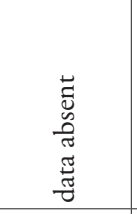 & 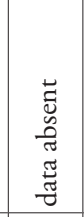 & 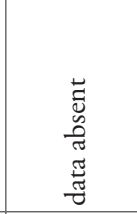 \\
\hline 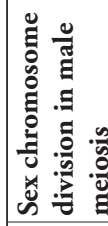 & 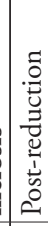 & 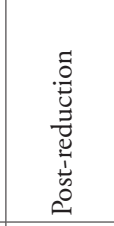 & 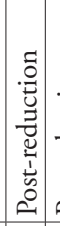 & 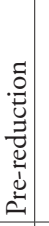 & 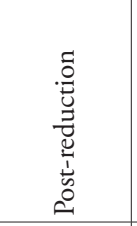 & 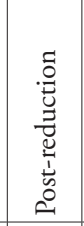 & 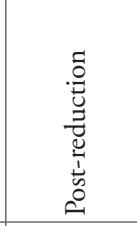 \\
\hline 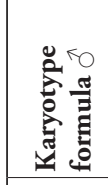 & 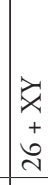 & 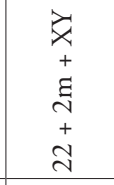 & 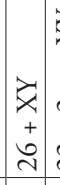 & 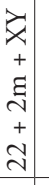 & $n$. & n. & \\
\hline సี & $\stackrel{\infty}{\sim}$ & 난 & $\stackrel{\infty}{\sim}$ & $\stackrel{2}{2}$ & తి & $\stackrel{\infty}{\sim}$ & 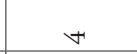 \\
\hline 窇 & 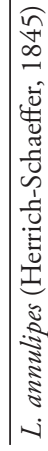 & 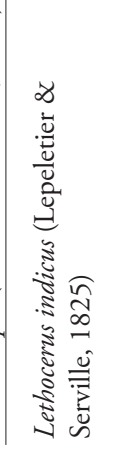 & 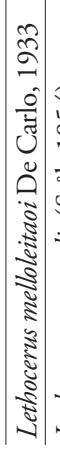 & 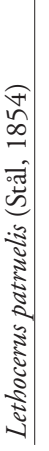 & 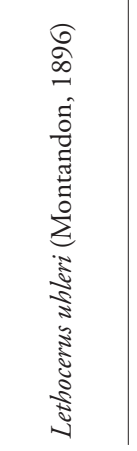 & 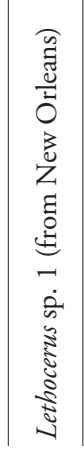 & 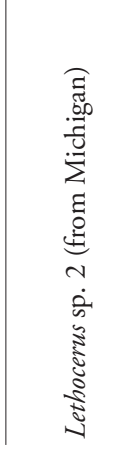 \\
\hline
\end{tabular}


in L. patruelis and suggested in L. uhleri, see Table 1). Within the genus, L. patruelis seems to be similar to $L$. indicus in chromosome complement. This resemblance is confined not only to chromosome number and the presence of $\mathrm{m}$-chromosomes but also to that the sex chromosomes in L. patruelis (present paper) and L. indicus (Bagga 1959, Jande 1959) are indistinguishable from autosomes at meiotic metaphases if a routine staining is used. In $L$. patruelis, it was due to the size resemblance of $\mathrm{X}$ and Y chromosomes causing the almost homomorphic form of the XY-pseudobivalent at MI. Noteworthy however that L. indicus was speculated to have the sex chromosome system of a neo-XY type originated as a result of the evolutionary translocation of both sex chromosomes to one pair of autosomes in the ancestral karyotype (Jande 1959). Another example of a neo-XY system seems to be Lethocerus sp. from Michigan. For this species, Chickering and Bacorn (1933) reported $2 n=4$ with no distinguishable sex chromosomes. These authors suggested that this karyotype might has originated via a translocation of $\mathrm{X}$ and $\mathrm{Y}$ chromosomes to one pair of autosomes with a subsequent fusion between two more pairs of autosomes.

Ueshima (1979) considered the karyotype of $2 n=24+2 m+X Y$ as the modal (the commonest) in the genus Lethocerus and the ancestral (i.e., plesiomorphic) one in its evolution. All other karyotypes were suggested to have originated from this ancestral one through autosome fusions and fragmentations, translocations of sex chromosomes to autosomes and loss of m-chromosomes (see Fig. 12 in Ueshima 1979). However, here it should be noted that the most common karyotype needs not to be plesiomorphic in a group (White 1973). In addition, the data available at that time for Lethocerus (see Table 4 in Ueshima 1979) were in fact not indicative of the modality of $2 \mathrm{n}=24$ $+2 \mathrm{~m}+\mathrm{XY}$ in the genus, and some data presented in Ueshima's scheme were not universally correct (Fig. 9). For example, in the karyotype formulae of some of the species (for instance Lethocerus sp. from New Orleans) Ueshima included m-chromosomes which however have not been mentioned in the original paper (Table 1).

On the other hand, the ancestrality of a XY sex determination in Lethocerus is beyond question, since neo-XY and $\mathrm{X}_{\mathrm{n}} \mathrm{Y}$ systems occurring in Belostomatidae (both), including Lethocerus (at least neo-XY), are clearly derivative being originated by X-autosome fusions or X-chromosome fissions, respectively. It cannot be doubted also that low chromosome numbers such as $2 \mathrm{n}=8$ in L. americanus and $2 \mathrm{n}=4$ in Lethocerus sp. from Michigan, are the derived characters brought about a series of autosome fusions during the course of evolution in this genus.

It seems likely that the ancestral karyotype in Lethocerus includes 26 autosomes and XY mechanism as found in many representatives of this genus and Belostomatidae as a whole (Table 1). It is not possible even to suggest whether this karyotype includes a pair of m-chromosomes as was speculated by Ueshima (1979). It is evident that these minute chromosomes easily escape detection by bug cytogeneticists, and hence many species recorded as lacking $\mathrm{m}$-chromosomes in fact have them in their karyotypes.

$\mathrm{CMA}_{3}$ staining of L. patruelis C-banded chromosomes revealed GC-rich sites corresponding to NORs in the $\mathrm{X}$ and $\mathrm{Y}$ chromosomes. This is the first case of NOR detection in Lethocerus. On the other hand, ribosomal genes have been already located in 


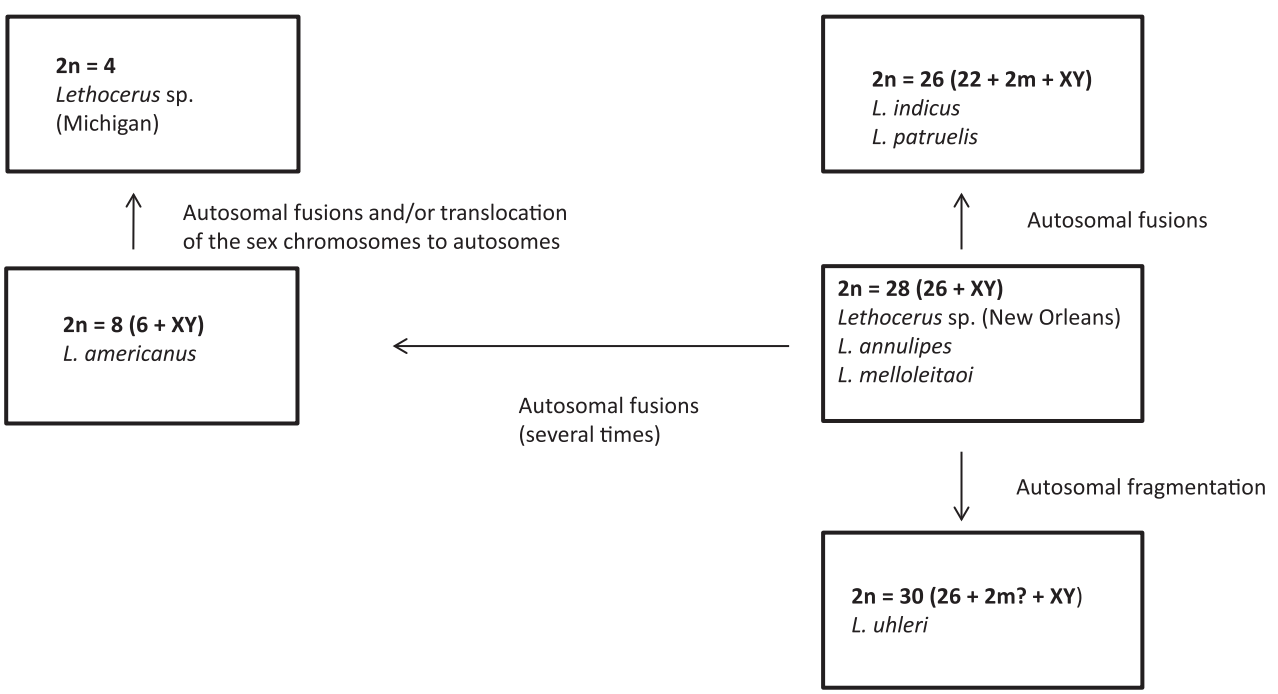

Figure 9. Suggested pathways of karyotype evolution in the genus Lethocerus.

Belostoma chromosomes using various techniques such as fluorochrome staining, silver staining and FISH (Table 1). In Belostoma, five species were shown to have NORs also in sex chromosomes while three other species in a pair of autosomes. Noteworthy, the species with the same chromosome complement sometimes differ in rDNA location (for example, in sex chromosomes in B. cummingsi while in autosomes in B. dentatum, both with $2 \mathrm{n}=26+\mathrm{X}_{1} \mathrm{X}_{2} \mathrm{Y}$ ).

In the greatest majority of living organisms, during the first division of meiosis all chromosomes reduce in number (reductional division), whereas during the second division the chromatids separate (equational division), and this pattern is named "pre-reduction" (White 1973). However true bugs characteristically have an inverted sequence of sex chromosome divisions in male meiosis, the so-called sex chromosome "post-reduction" when sex chromosomes undergo equational division at anaphase I and reductional division at anaphase II (Ueshima 1979, Kuznetsova et al. 2011), and this is also true for Belostomatidae (Table 1). Interestingly, L. patruelis appeared unique in showing no inverted sequence of sex chromosome divisions in male meiosis. In this species, $\mathrm{X}$ and $\mathrm{Y}$ chromosomes form a pseudobivalent at prophase and segregate to opposite poles at anaphase $I$, and the first division of meiosis is thus reductional both for autosomes and sex chromosomes. As a result of sex chromosome prereduction, second spermatocytes carry a single sex chromosome, either $\mathrm{X}$ or $\mathrm{Y}$. The second division is then equational for all the chromosomes. Although pre-reduction of sex chromosomes is not usual in Heteroptera, it does occur in some groups (for example, all so far studied species of the family Tingidae have shown pre-reduction; Ueshima 1979, Grozeva and Nokkala 2001). Moreover, closely related species occasionally differ in this pattern (Ueshima 1979, Grozeva et al. 2006, 2007) as is also true of Lethocerus species. 
Male meiosis in Heteroptera can further be characterized by radial configuration of one or sometimes both MI and MII plates. In this case, autosomal bivalents at MI and autosomes at MII form a ring on the periphery of the spindle, while the sex chromosomes are located in the center of this ring (Ueshima 1979). However in $L$. patruelis, both MI and MII plates are non-radial with random distribution of all the chromosomes on the spindle.

\section{Acknowledgements}

The study was supported for Snejana Grozeva and Nikolay Simov by DO-02-259 NSF Sofia, Bulgarian Academy of Sciences, and for Valentina Kuznetsova by the RFBR (grant 11-04-00734) and programs of the Presidium of the Russian Academy of Sciences "Gene Pools and Genetic Diversity" and "Origin of the Biosphere and Evolution of Geo-biological Systems". We thank S. Nokkala for making a valuable contribution to the interactive discussion of the meiotic images. We thank Z. Andreeva, S. Beshkov, V. Dimitrov, G. Hristov, E. Galabova, V. Gashtarov, D. Kajnarov, K. Popov, O. Sivilov, T. Stefanov, Zh. Vlaykov, B. Zlatkov for the help in collecting material and data.

\section{References}

Bagga S (1959) On the pre-reduction of the sex chromosomes during meiosis in a belostomatid, Lethocerus indicum. Proceedings of the Zoological Society (Calcutta) 12: 19-22.

Banerjee MK (1958) A study of the chromosomes during meiosis in twenty-eight species of Hemiptera (Heteroptera, Homoptera). Proceedings of the Zoological Society (Calcutta) 11: 9-37.

Bardella VB, Dias AL, Giuliano-Caetano L, Ribeiro JRI, Da Rosa R (2012) Sex chromosome differentiation in Belostoma (Insecta: Heteroptera: Belostomatidae). Genetics and Molecular Research 11 (3): 2476-2486. doi: 10.4238/2012.May.21.2

Bawa SR (1953) Studies on insect spermatogenesis. I. Hemiptera-Heteroptera. The sex chromosomes and cytoplasmic inclusions in the male germ cells of Laccotrephes maculatus Fabr. and Sphaerodema rusticum Fabr. Research Bulletin of the East Panjab University 39: 181192.

Buresch I (1940) Das tropische Riesen-Wasserinsekt Belostoma niloticum Stål. (Lethocerus cordofanus Mayr), gefunden in Bulgarien (Mit einer Karte der Verbreitung auf der BalkanHalbinsel). Mitteillungen der Bulgarischen Entomologischen Gesellschaft in Sofia 11: 138-160. [In Bulgarian, German summary]

Chickering AM (1916) A preliminary study of the spermatogenesis of Belostoma flumineum. Transactions of the American Microscopy Society 35: 45-53. doi: 10.2307/3221525

Chickering AM (1927a) An unusual complex in Lethocerus. The Anatomical Record 37: 156.

Chickering AM (1927b) Spermatogenesis in the Belostomatidae. II. The chromosomes and cytoplasmic inclusions in the male germ cells of Belostoma flumineum Say, Lethocerus ameri- 
canus Leidy, and Benacus griseus Say. Journal of Morphology and Physiology 44: 541-607. doi: 10.1002/jmor. 1050440308

Chickering AM (1932) Spermatogenesis in the Belostomatidae. III. The chromosomes in the male germ cells of a Lethocerus from New Orleans, Louisiana. Papers of Michigan Academy of Sciences 15: 357-360.

Chickering AM, Bacorn B (1933) Spermatogenesis in the Belostomatidae. IV. Multiple chromosomes in Lethocerus. Papers of Michigan Academy of Sciences 17: 529-534.

Conger A, Fairchild L (1953) A quick-freeze method for making smear slides permanent. Stain Technology 28: 281-283.

Fent M, Kment P, Çamur-Elipek B, Kirgiz T (2011) Annotated catalogue of Enicocephalomorpha, Dipsocoromorpha, Nepomorpha, Gerromorpha, and Leptopodomorpha (Hemiptera: Heteroptera) of Turkey, with new records. Zootaxa 2856: 1-84.

Grozeva S, Kuznetsova V, Anokhin B (2010) Bed bug Cimex lectularius Linnaeus, 1758 cytogenetics: karyotype, sex chromosome system, chromosomal location of $18 \mathrm{~S}$ rDNA, and male meiosis (Heteroptera, Cimicidae). Comparative Cytogenetics 4 (2): 151-160. doi: 10.3897/compcytogen.v4i2.36

Grozeva S, Nokkala S (2001) Chromosome number, sex chromosomes system and the distribution of constitutive heterochromatin in 13 lacebug species (Heteroptera, Tingidae). Folia Biologica (Krakòw) 49 (1-2): 29-41.

Grozeva S, Nokkala S, Simov N (2006) First evidence of sex chromosomes pre-reduction in male meiosis in the Miridae bugs (Heteroptera). Folia Biologica (Krakòw) 54 (1-2): 9-12. doi: 10.3409/173491606777919166

Grozeva S, Simov N, Josifov M (2007) Karyotaxonomy of some European Macrolophus species (Heteroptera, Miridae). Mainzer Naturwissenschaftliches Archiv 31: 81-87.

Jande SS (1959) An analysis of the chromosomes in the four species of the family Belostomatidae (Heteroptera, Cryptocerata). Research Bulletin (Natural Sciences) of the Panjab University 10: 25-34.

Josifov M (1960) Artenzusammensetzung und Verbreitung der Insekten von der Ordnung Heteroptera in Bulgarien. Teil I. Bulletin de l'Institut zoologique de l'Académie des sciences de Bulgarie 9: 107-177. [In Bulgarian, German summary]

Josifov M (1974) Die Heteropteren der bulgarischen Schwarzmeerküste. Bulletin de l'Institut de zoologie et musée 39: 5-25. [In Bulgarian, German summary]

Josifov M (1986) Verzeichnis der von der Balkanhalbinsel bekannten Heteropterenarten (Insecta, Heteroptera). Faunistische Abhandlungen, Staatliches Museum für Tierkunde in Dresden 14 (6): 61-93.

Josifov M (1999) Heteropterous insects in the Sandanski-Petrich Kettle, Southwestern Bulgaria. Historia naturalis bulgarica 10: 35-66.

Kuznetsova V, Grozeva S, Nokkala S, Nokkala C (2011) Cytogenetics of the true bug infraorder Cimicomorpha (Hemiptera, Heteroptera): a review. Zookeys 154: 31-70. doi: $10.3897 /$ zookeys. 154.1953

Kuznetsova VG, Grozeva S, Anokhin BA (2012) The first finding of (TTAGG) telomeric repeat in chromosomes of true bugs (Heteroptera, Belostomatidae). Comparative Cytogenetics 6 (4): 341-346. doi: 10.3897/CompCytogen.v6i4.4058 
Lauck DR, Menke AS (1961) The higher classification of the Belostomatidae. Annals of the Entomological Society of America 54: 644-657.

Montgomery TH (1901) A study of the chromosomes of the germ cells of Metazoa. Transactions of the American Philosophical Society 20: 154-236. doi: 10.2307/1005428

Montgomery TH (1906) Chromosomes and spermatogenesis of the Hemiptera-Heteroptera. Transactions of the American Philosophical Society 21: 97-173. doi: 10.2307/1005443

Muramoto N (1978) A chromosome study of thirty Japanese heteropterans (Heteroptera). Genetica 49 (1): 37-44. doi: 10.1007/BF00187812

Olivieri N (2009) Segnalazioni Faunistiche Italiane. 487. Lethocerus (Lethocerus) patruelis (Stål, 1854) (Heteroptera Belostomatidae). Bollettino della Societa Entomologica Italiana Genova 141 (2): 116.

Papeschi AG (1988) C-banding and DNA content in three species of Belostoma (Heteroptera) with large differences in chromosome size and number. Genetica 76: 43-51. doi: 10.1007/ BF00126009

Papeschi AG (1991) DNA content and heterochromatin variation in species of Belostoma (Heteroptera, Belostomatidae). Hereditas 115: 109-114.

Papeschi AG (1994) Chromosome rearrangements in Belostoma plebejum (Stål) (Belostomatidae, Heteroptera). Caryologia 47: 223-231.

Papeschi AG (1996) Sex chromosome polymorphism in a species of Belostoma (Belostomatidae, Heteroptera). Hereditas 124: 269-274. doi: 10.1111/j.1601-5223.1996.00269.x

Papeschi AG, Bidau CJ (1985) Chromosome complement and male meiosis in four species of Belostoma Latreille (Heteroptera - Belostomatidae). Brazilian Journal of Genetics 8: 249-261.

Papeschi AG, Bressa MJ (2006) Evolutionary cytogenetics in Heteroptera. Journal of Biological Research 5: 3-21. doi: 10.1186/jbiol30

Pendergrast JG (1957) Studies on the reproductive organs of the Heteroptera with a consideration of their bearing on classification. Transactions of the Royal Entomological Society of London 109: 1-63. doi: 10.1111/j.1365-2311.1957.tb00133.x

Perez Goodwyn PJ (2006) Taxonomic revision of the subfamily Lethocerinae Lauck and Menke (Heteroptera: Belostomatidae). Stuttgarter Beiträge zur Naturkunde (Serie A) (Biologie) 695: 1-71.

Polhemus JT (1995) Belostomatidae. In: Aukema B, Rieger C (Eds) Catalogue of the Heteroptera of the Palaearctic region. I. Netherlands Entomological Society, Amsterdam, 19-23.

Protić LD (1998) Catalogue of the Heteroptera fauna of Yugoslav countries. I. Special Issue of Natural History Museum, Belgrade, 38: 1-215.

Rabitsch W (2008) The times they are a-changin': Driving forces of recent additions to the Heteroptera fauna of Austria. In: Grozeva S, Simov N (Eds) Advances in Heteroptera Research. Festschrift in Honour of 80th Anniversary of Michail Josifov. Pensoft Publishers, Sofia, 309-329.

Ribeiro JRI (2007) A review of the species of Belostoma Latreille, 1807 (Insecta, Heteroptera, Belostomatidae) from the four southeastern Brazilian states. Zootaxa 1477: 1-70.

Schuh RT, Slater JA (1995) True Bugs of the World (Hemiptera: Heteroptera). Classification and Natural History. Cornell University Press, Ithaca, New York, xii + 338 pp. 
Tzonev R, Valchev V, Georgiev V (2011) Natural or semi-natural mesotrophic to eutrophic lakes and marshes with macrophytic vegetation. In: Biserkov V. (Ed) Red Data Book of the Republic of Bulgaria. Volume 3. Natural Habitats. Bulgarian Academy of Sciences, Ministry of Environment and Waters, Sofia, electronic publication, available at http://e-ecodb. bas.bg/rdb/en/vol3/ [last accessed September 2012]

Ueshima N (1979) Hemiptera II: Heteroptera. In: John B (Ed) Animal Cytogenetics. 3. Insecta 6. Gebrüder Bornträger, Berlin, Stuttgart, 113 pp.

White MJD (1973) Animal cytogenetics and evolution. Cambridge University Press, Cambridge, $961 \mathrm{pp}$.

\section{Appendix}

Electronic supplementary material video S1. (doi: 10.3897/zookeys.319.4384.app) File format: MPEG Video File (mpg).

Explanation note: A stalking/ambush attack of Lethocerus patruelis larva against small topmouth gudgeon (Pseudorasbora parva).

Copyright notice: This dataset is made available under the Open Database License (http://opendatacommons.org/licenses/odbl/1.0/). The Open Database License $(\mathrm{ODbL})$ is a license agreement intended to allow users to freely share, modify, and use this Dataset while maintaining this same freedom for others, provided that the original source and author(s) are credited.

Citation: Grozeva S, Kuznetsova VG, Simov N, Langourov M, Dalakchieva S (2013) Sex chromosome pre-reduction in male meiosis of Lethocerus patruelis (Stål, 1854) (Heteroptera, Belostomatidae) with some notes on the distribution of the species. In: Popov A, Grozeva S, Simov N, Tasheva E (Eds) Advances in Hemipterology. ZooKeys 319: 119-135. doi: 10.3897/zookeys.319.4384 Electronic supplementary material video S1. doi: 10.3897/zookeys.319.4384.app 